\title{
Assessment of Web Content Accessibility Levels in Spanish Official Online Education Environments
}

\author{
Rosabel Roig-Vila ${ }^{1}$, Sergio Ferrández ${ }^{1} \&$ Imma Ferri-Miralles $^{2}$ \\ ${ }^{1}$ Departamento de Didáctica General y Didácticas Específicas, Facultad de Educación, Universidad de Alicante, \\ Alicante, Spain \\ ${ }^{2}$ Departamento de Lingüística Aplicada, Universitat Politècnica de València, Escola Politècnica Superior d'Alcoi, \\ Alcoi, Alicante, Spain \\ Correspondence: Rosabel Roig-Vila. Departamento de Didáctica General y Didácticas Específicas, Facultad de \\ Educación, Universidad de Alicante, Ap. Correos 99, 03080 Alicante, Spain. Tel: 34-96-590-3721. E-mail: \\ rosabel.roig@ua.es
}

Received: February 24, 2014 Accepted: April 25, 2014 Online Published: May 20, 2014

doi:10.5539/ies.v7n6p31 URL: http://dx.doi.org/10.5539/ies.v7n6p31

\begin{abstract}
Diversity-based designing, or the goal of ensuring that web-based information is accessible to as many diverse users as possible, has received growing international acceptance in recent years, with many countries introducing legislation to enforce it. This paper analyses web content accessibility levels in Spanish education portals according to the international guidelines established by the World Wide Web Consortium (W3C) and the Web Accessibility Initiative (WAI). Additionally, it suggests the calculation of an inaccessibility rate as a tool for measuring the degree of non-compliance with WAI Guidelines 2.0 as well as illustrating the significant gap that separates people with disabilities from digital education environments (with a $7.77 \%$ average). A total of twenty-one educational web portals with two different web depth levels (42 sampling units) were assessed for this purpose using the automated analysis tool Web Accessibility Test 2.0 (TAW, for its initials in Spanish). The present study reveals a general trend towards non-compliance with the technical accessibility recommendations issued by the W3C-WAI group (97.62\% of the websites examined present mistakes in Level A conformance). Furthermore, despite the increasingly high number of legal and regulatory measures about accessibility, their practical application still remains unsatisfactory. A greater level of involvement must be assumed in order to raise awareness and enhance training efforts towards accessibility in the context of collective Information and Communication Technologies (ICTs), since this represents not only a necessity but also an ethical, social, political and legal commitment to be assumed by society.
\end{abstract}

Keywords: accessibility, disabilities, educational environment, eLearning, Internet

\section{Introduction}

\subsection{Introduce the Problem}

The ongoing evolution of Information and Communication Technologies (ICTs) stands out as one of the essential features of the Information Society (Castells, 2009), which provides easy access to global communication and allows us to talk through boundless information systems with no physical borders (Sangrà \& Wheeler, 2013). This tendency to work with online environments rather than printed materials is certainly changing (Ali, Wahid, Samsudin \& Idris, 2013). However, this is a change which requires constant adjustment. The temporal nature of knowledge requires a structure where training is replaced by staying up to date, that is, placing the latest developments within a real-time field (Aguirre \& Manasía, 2007).

Access to ICTs makes it possible to obtain information and communication not only more safely and easily, but also more quickly, regardless of our physical location (Llanos de la Hoz, 2006). Moreover, ICTs offer persons with a disability an opportunity for coping with the challenges in communication and socialising that they often encounter in their day-to-day life (Aguaded-Gómez \& Pérez-Rodríguez, 2012; Stendal, Balandin, \& Molka-Danielsen, 2011). Nevertheless, gaining access to all these information and technology developments can actually represent a double-edged sword for people with disabilities: whilst the information is suddenly more accessible to many individuals, it can also raise barriers and severe obstacles for other users who cannot access 
much of the content - for instance, when basic accessibility principles do not apply (Fairweather \& Trewin, 2010; Rodríguez \& García, 2009). Hence the need for further research on the connection between people with disabilities and their way of accessing web content (Van Kraayenoord, 2010).

Accessibility is a very broad concept. According to the World Wide Web Consortium (W3C), web accessibility means universal access to the Web regardless of the hardware, software or network infrastructure used and the language, culture, geographical location or abilities of users. Berners-Lee (2007) describes accessibility as "the art of ensuring that, to as large an extent as possible, facilities (such as, for example, Web access) are available to people whether or not they have impairments of one sort or another." Along these lines, guaranteeing accessibility through a diversity-based design seems essential to us. Design should provide as many human beings as possible with the freedom required to succeed by themselves within an increasingly friendly environment (Aragall, 2000). It must offer solutions to ensure that professionals can satisfy the highest possible number of users with their creative and technical work, through awareness of and respect for all needs.

\subsection{Designing for Everyone}

Neglecting the 'design-for-all' model is likely to affect a large part of the population. According to the Spanish National Statistics Institute (INE, for its initials in Spanish) the number of Spanish nationals with a disability amounts to $8.5 \%$ of the total population (Note 1). All these persons need ICTs not only to enhance their abilities, but also to compensate possible limitations. Hence the compelling necessity to make ICTs accessible so that this segment of the population can take full advantage of their potential.

The 1st Spanish National Accessibility Plan 2004-2012 (Ministerio de Trabajo y Asuntos Sociales, 2003) stated that "a society which fights for inclusiveness and respect for human beings must be a society which meets the needs of every person equally" (p. 7). Bertot and Jaeger (2006) suggested "Designing for Everyone"-set up under Law n. 51/2003 (2003) of Equal Opportunities, Non-Discrimination and Universal Accessibility for Persons with a Disability and Law n. 56/2007 (2007)-as the right way to guarantee equal opportunities for all.

Fortunately, ICTs provide easier access to contents for people with different abilities and profiles (Prendes, Castañeda \& Ovelar, 2014). However, the new developments in the field of technology will only benefit persons with a disability if emergent technologies are designed to be accessible (Zeng \& Parmanto, 2004; Ritchie \& Blanck, 2003; Baguma \& Lubega, 2008). Lack of access to ICTs hampers progress towards equal opportunities, subsequently creating a deep cultural, economic and social divide (Serrano \& Capdevila, 2011). Therefore, an effort must be made within ICT environments to apply the concept of universal accessibility-especially relevant during these times of rapid technological changes. Failing to implement this concept would not only hinder all the legal improvements made so far to foster equality among persons with a disability in terms of information society access but also prevent them from achieving their goals towards integration and independence (Jiménez, 2011; Fairweather \& Trewin, 2010).

\section{Critical Literature Review}

The W3C implemented the Web Accessibility Initiative (WAI) in order to establish Web Content Accessibility Guidelines (Note 2)-WCAG 1.0 and 2.0-that could regulate universal accessibility to website content. They include a wide range of recommendations to make web content more accessible and constitute the foundations of web accessibility in terms of legislation, research and development worldwide. In fact, web content can become accessible to a wider range of people with disabilities such as blindness and low vision, deafness and hearing loss, learning disabilities, cognitive limitations, limited movement, speech disabilities, photosensitivity and any combinations of these-and more usable to everyone too-thanks to compliance with these guidelines.

The WCAGs revolve around 4 principles that define web accessibility. An accessible website fully conforming to the WCAGs should be: Understandable (its contents or operations cannot be beyond the user's understanding); Operable (its interface cannot require any interactions that a user cannot perform); Perceivable (the information presented cannot be invisible to all of the user's senses); and Robust (the content should remain accessible as technologies and user agents evolve). Following these guidelines guarantees a diversity-based design of websites characterised by being more accessible and beneficial to users with or without a disability.

The aforementioned guidelines are at the root of most accessibility laws worldwide and provide the basis for many research studies dedicated to evaluating the accessibility degree of different websites. A number of studies have examined website conformance to WCAG 1.0 guidelines (see Table 1). 
Table 1. Key studies about web content accessibility

\begin{tabular}{|c|c|}
\hline Study focus & Authors \\
\hline \multirow[t]{2}{*}{ State government websites in the USA } & Goette, Collier, and Whilte (2006) \\
\hline & Lazar et al. (2010) \\
\hline Websites from four European Union states & Marincu and McMullin (2004) \\
\hline Nepal government websites & Shah and Shakya (2007) \\
\hline Brazilian municipalities websites & Freire, Bittar, and Fortes (2008) \\
\hline State legislative websites in the USA & Fagen and Fagen (2004) \\
\hline University websites in the USA & $\begin{array}{l}\text { Bradbard, Peters, and Caneva (2010); } \\
\text { Krach (2007) }\end{array}$ \\
\hline International university websites & $\begin{array}{l}\text { Kane, Shulman, Shockley, and } \\
\text { Ladner (2007) }\end{array}$ \\
\hline Study about website quality, which focused on blind users & $\begin{array}{l}\text { Lazar, Allen, Kleinnman, and } \\
\text { Malarkey (2007) }\end{array}$ \\
\hline $\begin{array}{l}\text { Determined the accessibility levels over time of several websites } \\
\text { arbitrarily chosen }\end{array}$ & Lazar and Greenidge (2006) \\
\hline Spanish and North American university libraries & $\begin{array}{l}\text { Caballero, Faba, and De Moya } \\
\text { (2009) }\end{array}$ \\
\hline $\begin{array}{l}\text { Suggested some straightforward assessment models for the } \\
\text { "cybermedia" }\end{array}$ & $\begin{array}{l}\text { Rodríguez, Codina, and Pedraza } \\
\text { (2010) }\end{array}$ \\
\hline $\begin{array}{l}\text { Revised the recommendations regarding credibility assessment and } \\
\text { online information accessibility }\end{array}$ & Metzger (2007) \\
\hline
\end{tabular}

It is equally important to acknowledge the efforts made by several Spanish organisations as a result of their strong commitment to accessible solutions at this point (Fernández-Soria, 2013). The network for Science and Business Development towards Communication Accessibility (CEPAC in Spanish); the Spanish National Organisation of the Visually Impaired (ONCE in Spanish) or the Spanish National Institute of Technologies and Communication (INTECO in Spanish), have the promotion of accessibility amongst their stated objectives (Jiménez, 2011; Riesco, 2009; Pérez, Linares, \& Vizcaino, 2007; Rodríguez \& García, 2009; García \& Rodríguez, 2008).

The positive implications for diversity-based design that stem from their efforts to reach accessibility are undeniably evident. CEPACC's main goal is to promote research and knowledge exchange with a view to improve ICT accessibility. Among the actions undertaken by ONCE in the field of ICT accessibility the Info-Accessibility Observatory 'Discapnet' stands out, applying its own methodology to carry out a technical analysis of accessibility combined with a usability assessment based on user experience. INTECO simultaneously manages the Reference Centre on Accessibility and Web Standards with the support of the CTIC Technology Centre (Note 3) (home to the W3C Spanish Office which has developed tools such as the Web Accessibility Test TAW (Note 4) for the essential purpose of making the websites of Central Administration bodies accessible to the highest possible number of users. However, despite all these initiatives and the efforts made to guarantee web accessibility, further research still needs to be conducted on the actual application of the standard regulations.

\section{Definition of Key Terms}

The familiarity and widespread circulation of regulations and standards on web accessibility with regard to website and web portal design does not necessarily mean that developers always abide by those rules. It is therefore of paramount importance to assess the degree of compliance with these basic guidelines as well as to elaborate instructions to make improvements that can guarantee the diversity-based design of websites at all times. 
Our paper consequently has as its main aim the provision of an overview of the current situation regarding web accessibility in Spanish education portals-public websites delivering multiple educational services available online and integrated into a single space which should legally comply with all the accessibility guidelines and facilitate interaction with users.

The services and information delivered in the aforementioned web spaces provide a way of communication with educational community members (teachers, students and parents). Such web portals have an enormous educational potential and allow us to be constantly up to date with the latest developments in the field of education. Apart from being useful, they place information, ideas, learning resources, teaching materials, training, support and knowledge at everyone's disposal. Ensuring that all these facilities are within easy reach of all users becomes essential and calls for a comprehensive assessment of the extent to which these portals comply with web accessibility standards.

Taking all the above into account, the three specific aims of our paper are: (i) To analyse the degree of web accessibility in Spanish education portals using TAW as a tool; (ii) To check if educational web portals comply with WCAG 2.0 specifications; and (iii) To analyse if automated tools play a decisive role when trying to assess whether a certain website is accessible or not.

\section{Methodology}

The free-access tool TAW 2.0, which checks WCAGs in their 2.0 version, was used to conduct our examination of these web portals. The accessibility guidelines are divided into different success criteria, which are in turn classified into three conformance levels according to their impact on final website accessibility. Three levels can be reached, namely: A, AA and AAA, the latter being the most restrictive one and, therefore, the one which permits the highest accessibility level.

In addition to establishing the three aforesaid conformance levels, TAW classifies accessibility warnings into three types: "Fail" (an automatically found problem which does not need a manual check; it is actually the violation of a guideline), "Not decided" (the problem found must be manually checked) and "Not reviewed" (it needs an entirely manual check). In other words, TAW may find a "Fail" warning on a web page, for instance, and that warning could belong to an A, AA or AAA type of guideline.

The reasons for choosing TAW as the instrument to conduct our research are the following: it is a software developed by the CTIC Foundation, an organisation which houses the W3C Spanish Office; it is the most widely used assessment tool in Spain and one of the most frequently used tools worldwide; and it allows us to perform a comprehensive analysis together with automated analyses.

The analyses and assessments carried out in the present research work focused on the study of automated warnings; in other words, those where the tool finds accessibility issues which do not need human supervision (called "Fails" by TAW) and may refer to guidelines classified as A, AA or AAA.

The statistical data of this study are specified next.

\subsection{The Sample}

Our sample includes 21 educational web portals (links accessed from the Spanish Ministry of Education website (Note 5)) with two different web depth levels (Note 6)-42 in total. Such educational portals belong to the different Spanish Autonomous Regions, to the Ministry of Education and to the Institute of Educational Technology (IET in Spanish), respectively.

\subsection{Data Analysis}

The sampling plan is intentional and non-probabilistic; all sampling units contain ample qualified information.

\subsection{Assessment Tool and Analysis Criterion}

The automated analysis online software TAW was the tool used for the assessment of web accessibility in the 42 sample items. The analysis criterion followed during the evaluation and therefore requested from TAW stems from the WCAG 2.0 Guidelines.

\subsection{Limitations}

Certain accessibility features can only be checked manually and are consequently beyond the scope of our research, which focuses on automated validation.

The objective set in the present study was to assess automated warnings detected by TAW (i.e. those which do not need human supervision in order to be unquestionably regarded as violations of WCAG 2.0 Guidelines). Warnings belonging to the "Not decided" and "Not reviewed" types are thus left aside for other studies about 
non-automated features.

\subsection{Qualitative Analysis}

Besides the web accessibility assessment carried out with the online software TAW, we complemented our study with a more qualitative approach and filmed a number of in-depth interviews with real users with a disability in order to explore their real needs regarding web content accessibility. Participants with visual, physical or auditory impairment expressed their opinions and concerns about the main challenges they tend to encounter when navigating, their preferences, recommendations, etc.

\section{Results}

The focus will firstly be placed on showing the general results provided by TAW that can later permit to analyse the degree of web content accessibility in the website examined. Figure 1 specifies the number of warnings reported according to typology and conformance levels, level A conformance standing out as the one most often violated.

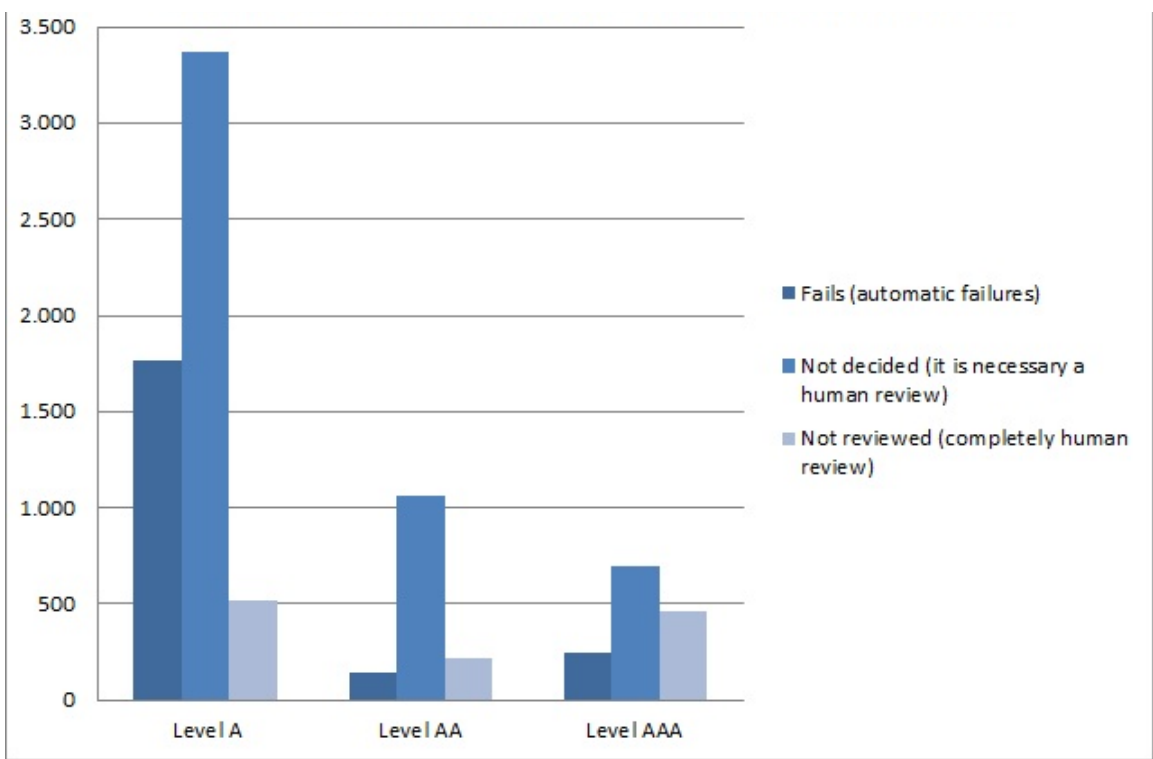

Figure 1. Number of warnings by type and conformance level

It can also be inferred from these first general results that the "Not reviewed" type accounts for $14 \%$ of the warnings; $61 \%$ of the warnings are "Not decided" and the remaining $25 \%$ belong to the "Fail" type - the automated errors on which our assessment is based (see Figure 2). 


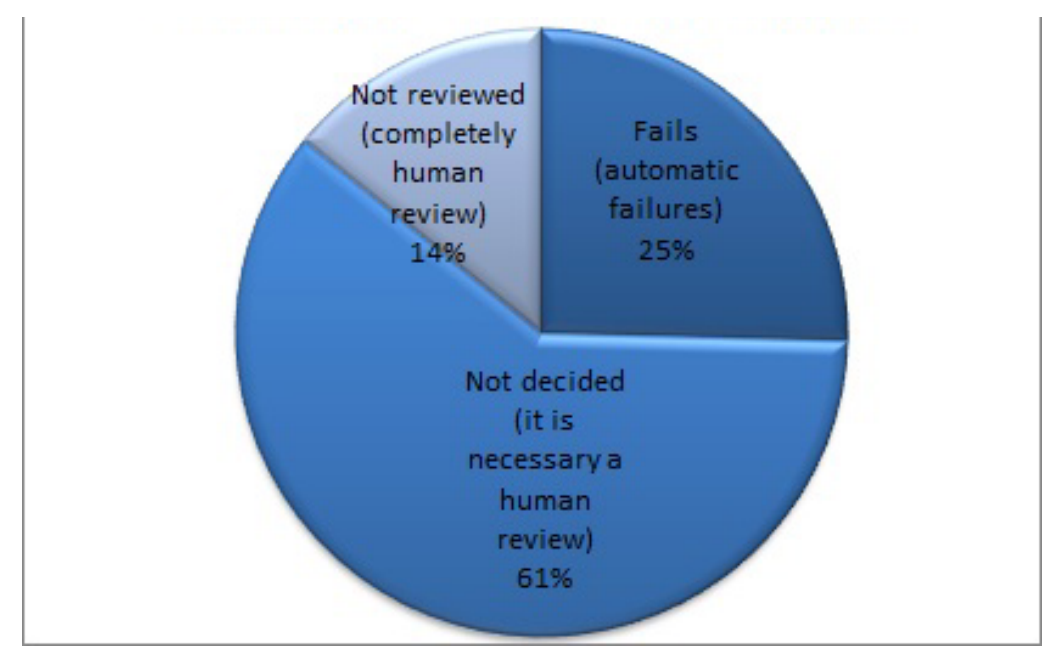

Figure 2. Percentage of warnings by type

The number of warnings on each website along with their typology clearly shows that the only website which does not generate automated errors is the web-depth-level-2 Madrid Regional Department of Education website. However, its specific accessibility level cannot be determined beforehand because that would require checking a high number of warnings-over 200-manually. To this must be added the fact that the web-depth-level-2 Valencian Region website shows the highest number of errors (466), followed by the level-1 website of the Canary Islands, with 230 errors.

The count of errors allows us to state that $97.6 \%$ of the websites analysed do not meet the necessary requirements to obtain the Level A accessibility certification (see Figure 3). Non-compliance percentage also exceeds $50 \%$ in the remaining two levels.

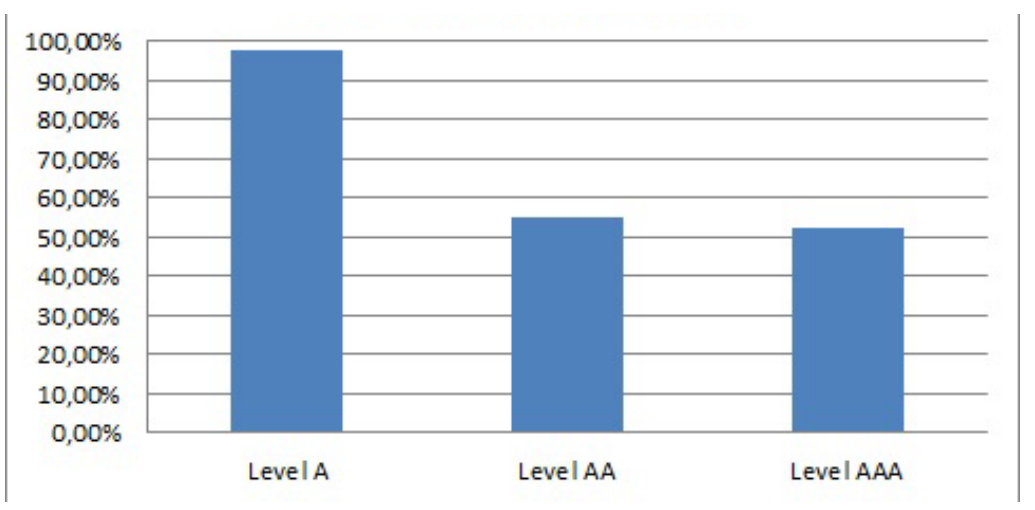

Figure 3. Percentage of websites which do not match each conformance level

The count of errors according to conformance level together with the calculation of an average for the 42 sampling units gives us an average figure of 4.74 errors per website. The highest average number of errors-3.29-corresponds to Level A conformance; Level AA conformance shows an average of 0.55 automated errors per website and average Level AAA conformance sits at 0.90 errors (see Figure 4). 


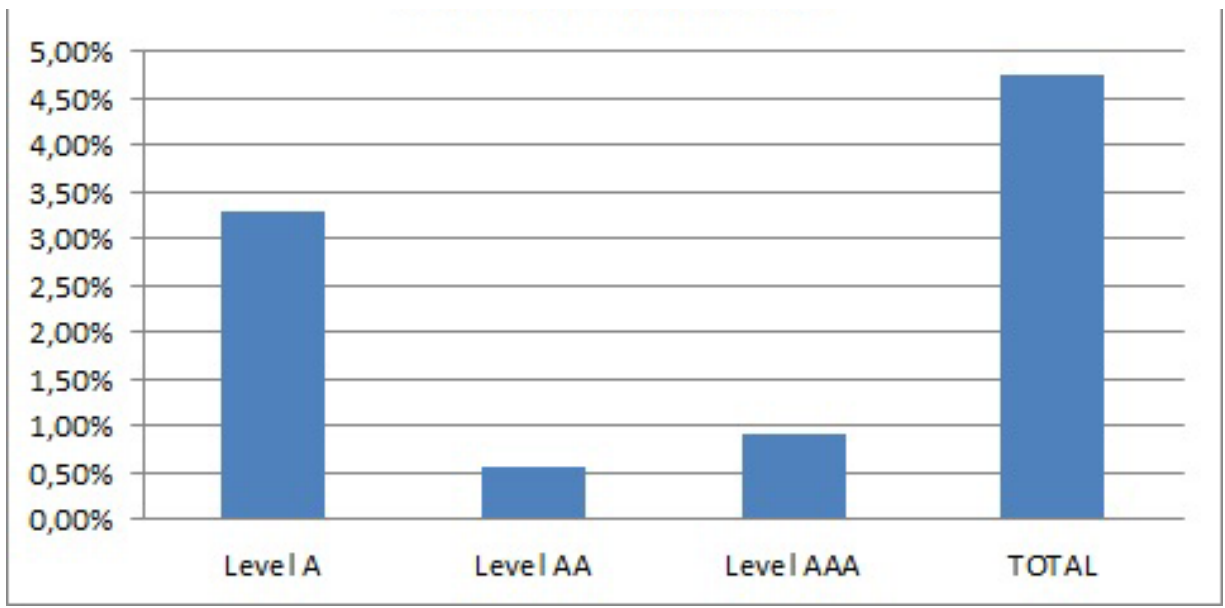

Figure 4. Average number of errors by conformance level

\subsection{WAI Checkpoints with the Highest Percentage of Errors}

Having shown the more general results, our attention now focuses on the checkpoints for those guidelines where websites fail - and the percentage that they represent over the total number of websites analysed-grouping the checkpoints together according to their conformance levels.

Table 2 specifies the number of websites failing in each one of the guideline checkpoints within Level A conformance, as well as the percentage of websites which fail in that checkpoint with respect to the 42 websites analysed. It is worth emphasising at this point that the main problems which arise on this level are "1.3.1-Info and relationships"-violated in $69 \%$ of the websites-and "4.1.1-Parsing"-which fails in $64.3 \%$ of the websites.

Table 2. Number and percentage of websites which fail in Level A conformance (grouped by WAI checkpoint)

\begin{tabular}{lll}
\hline & $\begin{array}{l}\text { Number of failing } \\
\text { Websites }\end{array}$ & $\begin{array}{l}\% \text { of } \\
\text { failing } \\
\text { Websites }\end{array}$ \\
\hline Understandable & 17 & $40.48 \%$ \\
3.1 Readable. 3.1.1-Language of Page & 7 & $16.67 \%$ \\
3.3 Input Assistance. 3.3.2-Labels or Instructions & & \\
Operable & 8 & $19.05 \%$ \\
2.1 Keyboard accessible. 2.1.1-Keyboard & 1 & $2.38 \%$ \\
2.2 Enough time. 2.2.2-Pause, stop, hide & 1 & $2.38 \%$ \\
2.2 Enough time. 2.2.1-Timing adjustable & 17 & $40.48 \%$ \\
2.4 Navigable. 2.4.4-Link purpose (in context) & 2 & $4.76 \%$ \\
2.4 Navigable. 2.4.2-Page titled & & $45.24 \%$ \\
Perceivable & 19 & $69.05 \%$ \\
1.1 Text alternatives. 1.1.1-Non-text content & 29 & $64.29 \%$ \\
1.3 Adaptable. 1.3.1-Info and relationships & & $23.81 \%$ \\
Robust & 27 & \\
4.1 Compatible. 4.1.1-Parsing & 10 & \\
4.1 Compatible. 4.1.2-Name, role, value & & \\
\hline
\end{tabular}


The 4 most frequently violated checkpoints among WCAG 2.0 guidelines are listed and described below with the aim of helping the reader to understand and visualize the most common accessibility errors in Level A conformance:

- "1.3.1 Info and Relationships: the information, structure, and relationships conveyed through a presentation can be programmatically determined or be available in text. The aim of this checkpoint is to ensure that the information and relationships implied by visual or auditory formatting are preserved when the presentation format is modified. For instance, the presentation format changes when the content is read by a screen reader or when a user style sheet is replaced with another style sheet provided by the author. Therefore, users who are blind (using a screen reader) benefit when information conveyed through colour is also available through text (i.e. including text alternatives for images that use colour to convey information). Also, users who are deaf-blind using braille (text) refreshable displays may be unable to access colour-dependent information." This checkpoint tends to fail in website forms with required fields, for example, as they are usually indicated with a red asterisk. Users with the aforementioned disabilities might not be able to perceive them.

- "4.1.1 Parsing: elements have complete start and end tags in the content implemented using mark-up languages; elements are nested according to their specifications; elements do not contain duplicate attributes, and any IDs are unique, except where the specifications allow these features." Failing to do so means that a user dependent on assistive technologies, such as a blind person using a screen reader, will not be able to access the content reliably as the content cannot be read properly.

- "3.1.1 Language of Page: The default human language of each Web page can be programmatically determined. The goal in this checkpoint lies in ensuring that content developers provide the web page with all the information that user agents need to present text and other linguistic contents correctly. Both assistive technologies and conventional user agents can render text more accurately when the web page language is identified, since screen readers can load the correct pronunciation rules, visual browsers can display characters and scripts correctly, and media players can show captions correctly too. As a result, users with disabilities will find it easier to understand the content." Failing to respect this checkpoint will make the website inaccessible to users who find it hard to read written material fluently and accurately and have difficulty in recognising characters and alphabets or decoding words and also to users with certain cognitive, language and learning disabilities who use text-to-speech software.

- "2.4.4 Link Purpose (In Context): The purpose of each link can be determined from the link text alone or from the link text together with its programmatically determined link context, except where the purpose of the link might be ambiguous to users in general. This checkpoint has as its main aim to help users to understand the purpose of each link so that they can decide whether they want to follow the link or not." An example of good design following this criterion would be: A page contains the sentence "Learn more about the Government of Ireland's Commission on Electronic Voting at Go Vote!» where "Go Vote!" is a link. Users with cognitive limitations will not become disoriented by multiple means of navigation to and from content that they are not interested in, and users with visual disabilities will be able to determine the purpose of a link by exploring the link's context.

As for level AA conformance, it can be determined from our assessment that the guideline "1.4.4 Resize text" appears as the main issue in the dimension of the Perceptible. $54.8 \%$ of the websites fail in this checkpoint, which seeks to ensure that visually rendered text -including text-based controls- can be successfully scaled so that it can be read directly by people with mild visual disabilities without requiring the use of assistive technology such as a screen magnifier. Users may benefit from scaling all the contents on the web page, but text is most critical.

Finally, the two accessibility checkpoints which fail the most with regard to level AAA conformance (see Table 3) belong to the "Operable" group:

- "2.4.9 Link Purpose (Link Only): A mechanism is available to allow the purpose of each link to be identified from link text alone, except where the purpose of the link might be ambiguous to users in general. For example: An icon of a voting machine and the text «Government of Ireland's Commission of Electronic Voting» are combined to make a single link."

- "2.4.10 Section Headings: They are used to organise the content. This checkpoint has as its aim to provide headings for a web page section when a page is organised into sections." For instance, blind users will know when they have moved from one web page section to another and thus identify the purpose of each section; and users who navigate content by keyboard will be able to jump focus from heading to heading, which enables them to find content of interest quickly. 
It consequently becomes obvious that failing to comply with some guidelines can affect users with various types of disability. Violating an easy-to-respect guideline such as giving users enough time to read and use content can imply the website content will remain inaccessible to users with physical disabilities, blind users or those with low vision, users with cognitive or language limitations, or users who are deaf and communicate using sign language, for example.

Table 3. Number and percentage of websites which fail in level AAA conformance by WAI checkpoint

\begin{tabular}{llc}
\hline & $\begin{array}{l}\text { Number of } \% \text { of failing } \\
\text { failing Websites }\end{array}$ & $\begin{array}{c}\text { Websites } \\
\text { Understandable }\end{array}$ \\
3.2 Predictable. 3.2.5-Change on request & 1 & $2.38 \%$ \\
Operable & & $19.05 \%$ \\
2.1 Keyboard accessible. 2.1.3-Keyboard (no exception) & 8 & $2.38 \%$ \\
2.2 Enough time, 2.2.4-Interruptions & 1 & $40.48 \%$ \\
2.4 Navigable. 2.4.9-Link purpose (link only) & 17 & $26.19 \%$ \\
2.4 Navigable. 2.4.10-Section headings & 11 & \\
\hline
\end{tabular}

\subsection{Inaccessibility Rate}

The term Inaccessibility Rate (see Figure 5) was incorporated into our research in order to measure the level of failure to execute WAI Guidelines 2.0. This rate reflects the proportion of checkpoints which result in a "Fail" warning over the total number of checkpoints examined. In other words, the lower this rate is the more accessible the assessed web page will be. Our new indicator specifies the degree of non-compliance with accessibility standards.

In short, Inaccessibility Rate becomes a useful piece of information for web designers to quantitatively and accurately evaluate the web accessibility of their developments. 


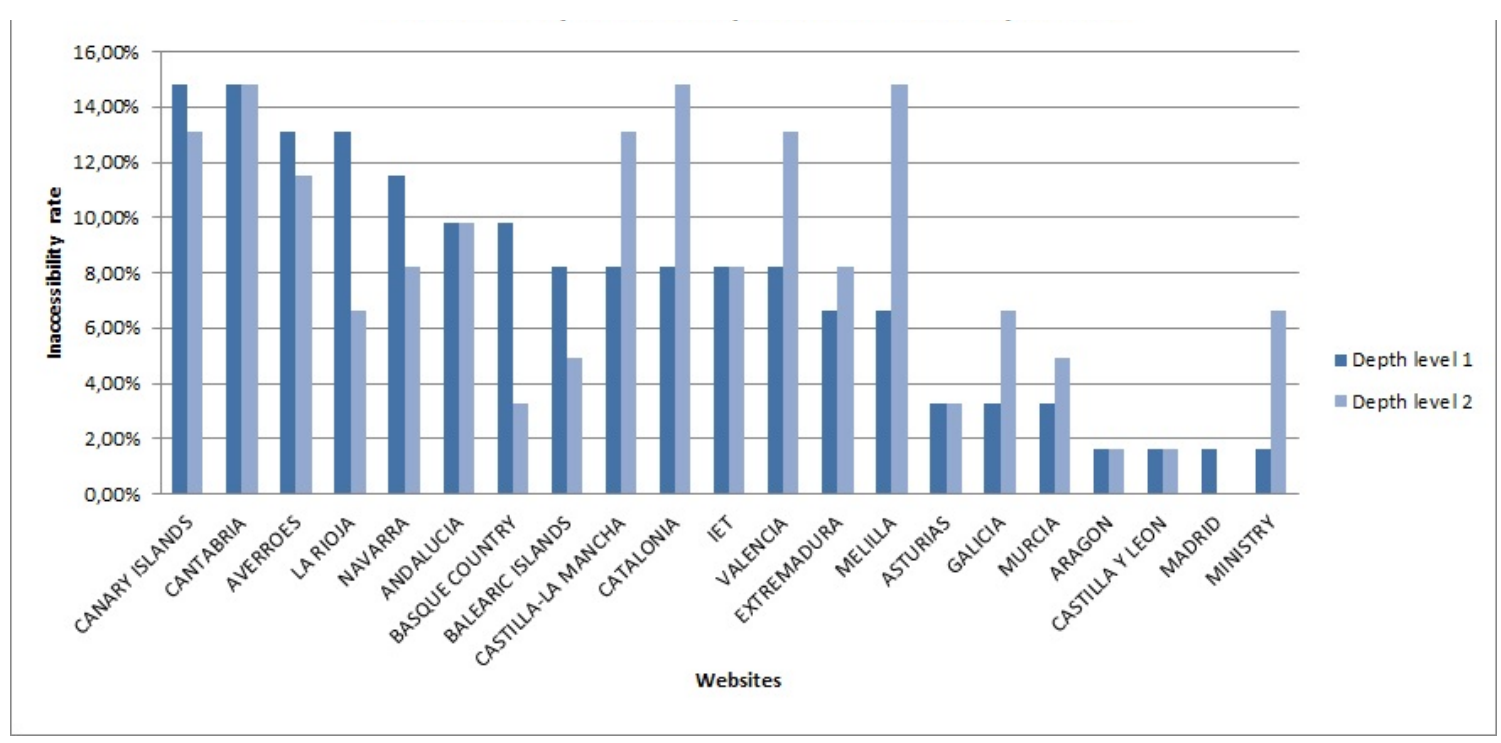

Figure 5. Inaccessibility rate of every website for each depth level

Table 4 distributes the websites analysed according to their inaccessibility rate values into three differently-sized groups with equidistant steps and a width of five points. It deserves to be highlighted here that " $10-15 \%$ " is the group of websites presenting the highest number of failed WAI Checkpoints. This group is formed by 12 websites which account for $28.57 \%$ of the total number of websites examined and show an average $13.52 \%$ Inaccessibility Rate.

Table 4. Segmentation of websites according to their inaccessibility rate

\begin{tabular}{llll}
\hline & $\begin{array}{l}\text { Number } \\
\text { of } \\
\text { Websites }\end{array}$ & \% of Websites & $\begin{array}{l}\text { Average } \\
\text { Inaccessibility Rate }\end{array}$ \\
\hline Most inaccessible websites. 10-15\% & 12 & $28.57 \%$ & $13.52 \%$ \\
$5-10 \%$ & 16 & $38.10 \%$ & $7.99 \%$ \\
Most accessible websites. 0-5\% & 14 & $33.33 \%$ & $2.58 \%$ \\
Total & 42 & $100.00 \%$ & $7.77 \%$ \\
\hline
\end{tabular}

\section{Discussion and Conclusion}

The main objective in our research was to obtain an overview of the current situation regarding web accessibility in Spanish education portals. Low web accessibility levels need to be highlighted in the first place: $54.76 \%$ of the websites present mistakes in level AA conformance (the minimum acceptable accessibility standard), a percentage that goes up to $97.62 \%$ in Level A conformance, and over $50 \%$ of websites do not match Level AAA conformance requirements.

At the same time, it can be seen that the main common errors for Level A conformance are "Info and Relationships" and "Parsing" (with $69 \%$ and $64 \%$ of the websites failing in these two WAI checkpoints, respectively). This means not only that more than half of the portals do not provide the information, structures and relationships in their presentations which could be offered differently (through text, audio or visual) but also that over $50 \%$ of them use language, marks or tags which can lead users to make mistakes. As for Level AA conformance, the checkpoint "Text Resize" fails in $54.8 \%$ of the websites analysed, which shows that text cannot be resized in any of these websites without the support of additional technology. The two checkpoints which fail the most with regard to Level AAA conformance are "Link Purpose" and "Section Headings;" $40.48 \%$ of the websites do not have a mechanism which permits the identification of the purpose of each link through text, and 
26.19\% fail when using headers or titles to organize content.

Our research also has as its second objective to check the extent to which educational web portals comply with the WCAG 2.0 Guidelines. Out of 42 sampling units analysed, only the web-depth-level-2 Madrid Regional Department of Education website matches all three automated levels. On the whole, results reveal the presence of considerable accessibility barriers that go against the suggestions of the international consortium in the rest of samples assessed.

Finally, our third objective, which consisted in verifying that the assessment of automated web accessibility is essential when it comes to determining the extent to which web spaces are accessible, has been proved both by our results and by the findings of previous studies.

Previous literature also used automated tools to examine websites in search of web accessibility-related problems. After admitting the limitations of automated analysis, several authors reached the conclusion that if a certain level is not obtained with an automated tool, that level cannot possibly be reached manually (Freire, Bittar, \& Fortes, 2008; Vigo \& Brajnik, 2011; Buhler, Heck, Perlick, Nietzio, \& Ulltveir-Moe, 2006). The results obtained in our study match the uniformly negative trends for diversity-based design of other research studies. Zeng and Parmanto (2004) checked that website inaccessibility was widespread and also found a correlation between accessibility web barriers and the popularity of a website (the variable representing the popularity of a website was measured by its visit traffic).

These authors found the correlation between accessibility web barriers and the popularity of a website to be statistically significant $(\mathrm{r}=0.28, \mathrm{P}<0.05)$. The main reasons for this accessibility-popularity correlation actually include the possibility that people become aware that a website is accessible and thus tend to visit it often, or that web developers of accessible websites spend more time making sure that their websites are appropriate in following other usability rules that make visiting easier for the public.

Lazar and Greenidge (2006) also argued that an accessible website increases the number of users, which in turn improves the organisation's profit. This supports the idea that complying with standards is beneficial not only to Internet users but also to website developers and owners (Bravo, 2006) and highlights the benefits of diversity-based design. In keeping with our conclusions, the analysis of 62 Catalan library websites carried out by López, Méndez, and Sorli (2002) showed that $90 \%$ of them did not meet some of the WGAG 1.0 requirements.

One would expect web accessibility to be gradually improving, but the most recent studies in this field show that there is still a long way to go. According to the information provided by the Info-accessibility Observatory Discapnet in 2008, only $36 \%$ of town hall portals in Spanish provincial capitals fulfill the basic accessibility requirements of diversity-based design.

A similar situation exists in the international context: Petrie, King, and Hamilton (2005) proved that less than half of the English museum web portals, libraries and archives analysed comply with the basic accessibility guidelines. In turn, Marincu and McMullin (2004) automatically demonstrated with a total of 5,000 samples that $94 \%$ of UK websites and $95 \%$ and $98 \%$ in Germany and France respectively, did not match Level A conformance guidelines. Finally, Goette et al. (2006) found that $98 \%$ of the 50 websites in the state of Columbia analysed were not accessible either.

Krach (2007) compared the data obtained from an automated assessment which covered the websites of 50 North American universities with the data collected by Zaphiris and Ellis (2001) about the same universities; 30\% of these universities met Level A conformance in 2001, a percentage which rose to $58 \%$ in 2007. Kane et al. (2007) showed that 100 websites from international universities had several accessibility obstacles. Authors like Bradbard et al. (2010) also acknowledge this trend, recognising generalised inaccessibility in North American university websites. In fact, accessibility still represents a problem for a wide range of public administration web portals.

A review of the previous literature together with the results of the present research work leads us to reach the following conclusions:

1) This study set out to determine the degree of web accessibility in Spanish education portals. After conducting our study with TAW, it becomes obvious that accessibility levels are low despite the current information and communication policies in Spain, according to which the creation of technologies, products and services must always follow accessibility principles.

2) The results of this study show that education web portals do not comply with WCAG 2.0 specifications. As suggested by the findings, the level is still far from satisfactory since web designers have not met the basic 
accessibility guidelines which define web accessibility.

3) Another significant finding that emerges from our study is related to whether automated tools are decisive when trying to assess a website's accessibility. The accessibility analysis performed in our study proves the effectiveness of automated validation to check that web portals are not accessible.

These findings have a number of important implications for future practice and suggest several courses of action for different professional groups:

1) Web designers should increase their efforts to respect the common web accessibility guidelines. Although new technologies, the rise of User-Generated Content (UGC) and the neutrality of accessibility guidelines pose a professional challenge for developers in search of accessibility solutions, the strongly committed activity of institutions such as $\mathrm{W} 3 \mathrm{C}$ provides the developers' community with a wide range of solutions and technological guidelines.

2) Public institutions must guarantee that the content of their websites is accessible to all citizens. Unless governments adopt these guidelines as a reference for public websites, universal web accessibility will never be attained. Web accessibility is not only a necessity but also an ethical, social, political and legal commitment to be assumed by society.

3) Although the number of legal and regulatory measures about web accessibility is increasingly high, their practical application still remains unsatisfactory. That is why disability advocate groups should continue to use high-impact litigation in order to secure the right to equal opportunities for people with various types of disabilities.

These conclusions are in agreement with the opinion of the users that participated in the assessment sessions.. Even though it is beyond the scope of this article to analyse these interviews thoroughly, it could be enlightening to remark on some of the opinions regarding the users' difficulties to access web contents. One of the recurrent feelings was indignation, and one of the participants manifested how "it seems that logics and the Internet are not compatible" (Participant 1). We could perceive a generalised frustration with the lacking financial investment made on accessibility solutions and with the way in which governments "generally spend on other things which may not be so necessary or don't infringe so much the right of a person to exercise their citizenship" (Participant 2). There is a generalized sentiment of unsatisfaction and a thirst for improvement and for a steady advancement towards quality accessibility solutions.

Improving web accessibility actually means improving the foundations of a twenty-first-century society as well as consolidating the actual Web 2.0 approach, which gives priority to applications devised to facilitate information sharing, interoperability, user-centred design and Web-based collaboration. In this respect, diversity-based design must be understood as an essential method for the creation of an egalitarian society where every citizen can participate on an equal footing. The design of accessible products needs to be promoted, thus making an effort to meet the needs of the highest possible number of users as far as access to the Internet is concerned.

\section{References}

Aguaded-Gómez, I., \& Pérez-Rodríguez, M. (2012). Strategies for media literacy: Audiovisual skills and the citizenship in Andalusia. Journal of New Approaches in Educational Research, 1(1), 22-26. http://dx.doi.org/10.7821/naer.1.1.22-26

Aguirre, A., \& Manasía, F. (2007). La habilitación digital para el desarrollo del comercio electrónico en el sector educativo [Digital empowerment for the development of electronic commerce in the educational sector]. Telematique: Revista Electrónica de Estudios Telemáticos, 6(3), 50-64. Retrieved from http://www.urbe.edu/publicaciones/telematica/indice/pdf-vol6-3/4-la-habitacion-digital.pdf

Ali, A. Z. M., Wahid, R, Samsudin, K., \& Idris, M. Z. (2013). Reading on the computer screen: Does font type has effects on web text readability? International Education Studies, 6(3), 26-35. http://dx.doi.org/10.5539/ies.v6n3p26

Aragall, F. (2000). Diseño para todos. Un conjunto de instrumentos [Design for All. A collection of tools]. Madrid, Fundación ONCE.

Baguma, R., \& Lubega, J. (2008). A web design framework for improved accessibility for people with disabilities (WDFAD). W4A'08 Proceedings of the 2008 International Cross-disciplinary Conference on Web Accessibility (W4A) (pp. 134-140). New York: ACM. http://dx.doi.org/10.1145/1368044.1368077

Berners-Lee, T. (2007). The future of the web. Retrieved from 
http://dig.csail.mit.edu/2007/03/01-ushouse-future-of-the-web.html

Bertot, J., \& Jaeger, P. (2006). User-centered e-government: Challenges and benefits for government websites. Government Information Quarterly, 23(2), 163-168. http://dx.doi.org/10.1016/j.giq.2006.02.001

Bradbard, D. A., Peters, C., \& Caneva, Y. (2010). Web accessibility policies at land-grant universities. Internet and Higher Education, 13(4), 258-266. http://dx.doi.org/10.1016/j.iheduc.2010.05.007

Bravo, A. (2006). Accesibilidad web: Un problema pendiente [Web Accessibility: a pending issue]. Didáctica, Innovación y Multimedia, 1(4), 1-23.

Buhler, C., Heck, H., Perlick, O., Nietzio, A., \& Ulltveir-Moe, N. (2006). Interpreting results from large scale automatic evaluation of web accessibility. In K. Miesenberger, J. Klaus, W. L. Zagler, \& A. I. Karshmer (Eds.), Computers Helping People with Special Needs (pp. 184-191). Heidelberg: Springer Berlin. http://dx.doi.org/10.1007/11788713_28

Caballero, L., Faba, C., \& De Moya, F. (2009). Evaluación comparativa de la accesibilidad de los espacios web de las bibliotecas universitarias españolas y norteamericanas [Comparative evaluation of accessibility in the websites of Spanish and American university libraries]. Investigación Bibliotecológica, 23(47), 45-66. Retrieved from http://www.ejournal.unam.mx/ibi/vol23-47/IBI002304703.pdf

Castells, M. (2009). Comunicación y poder [Communication and power]. Madrid: Alianza.

Fagen, J., \& Fagen, B. (2004). An accessibility study of state legislative websites. Government Information Quarterly, 21(1), 65-85. http://dx.doi.org/10.1016/j.giq.2003.12.010

Fairweather, P., \& Trewin, S. (2010). Cognitive impairments and Web 2.0. Universal Access in the Information Society, 9(2), 137-146. http://dx.doi.org/10.1007/s10209-009-0163-2

Fernández-Soria, J. (2013). Problems and challenges for the Politics of Education before the change of prominence experienced by educational actors. Journal of New Approaches in Educational Research, 2(2), 63-71. http://dx.doi.org/10.7821/naer.2.2.63-71

Freire, A., Bittar, T., \& Fortes, R. (2008, March). An approach based on metrics for monitoring web accessibility in Brazilian municipalities' websites. Proceedings of the ACM Symposium on Applied Computing (pp. 2421-2425). New York: ACM. http://dx.doi.org/10.1145/1363686.1364259

García, A., \& Rodríguez, A. (2008). Las TIC en el campo de la educación especial: Aportaciones y potencialidades [ICTs in the field of special education: Contributions and potential]. In R. Martínez (Coord.), Interactividad digital. Nuevas estrategias en educación y comunicación (pp. 113-130). Madrid: EOS.

Goette, T., Collier, C., \& Whilte, J. (2006). An exploratory study of the accessibility of state government websites. Universal Access in the Information Society, 5(1), 41-50. http://dx.doi.org/10.1007/s10209-006-0023-2

Jiménez, L. (2011). El estado actual de la accesibilidad de las tecnologías de la información y la comunicación (TIC) [The current state of affairs regarding the accessibility of information and communication technologies (ICTs)]. Madrid: Grupo Editorial Cinca. Retrieved from http://sid.usal.es/idocs/F8/FDO25714/estado_actual_accesibilidad.pdf

Kane, S., Shulman, J., Shockley, T., \& Ladner, R. (2007). A web accessibility report card for top international university websites. W4A'07 Proceedings of the International Cross-disciplinary Conference on Web Accessibility (W4A). New York: ACM. http://dx.doi.org/10.1145/1243441.1243472

Krach, S. K. (2007). Ten years after the law: A survey of the current status of university web accessibility. Journal of Special Education Technology, 22(4), 30-40.

Law n. 51/2003. (2003). Boletín oficial del Estado, Madrid, España, 3 December 2003. Retrieved from http://www.boe.es/boe/dias/2003/12/03/pdfs/A43187-43195.pdf

Law n. 56/2007. (2007). Boletín oficial del Estado, Madrid, España, 29 December 2007. Retrieved from http://www.boe.es/boe/dias/2007/12/29/pdfs/A53701-53719.pdf

Lazar, J., \& Greenidge, K. D. (2006). One year older, but not necessarily wiser: An evaluation of homepage accessibility problems over time. Universal Access in the Information Society, 4(4), 285-291. http://dx.doi.org/10.1007/s10209-003-0087-1

Lazar, J., Allen, A., Kleinnman, J., \& Malarkey, C. (2007). What frustrates screen reader users on the web: A 
study of 100 blind users? International Journal of Human-Computer Interaction, 22(3), 247-269. http://dx.doi.org/10.1080/10447310709336964

Lazar, J., Beavan, P., Brown, J., Coffey, D., Nolf, B., Poole, R., . . . Wenger, B. (2010). Investigating the accessibility of state government websites in Maryland. In P. Langdon, P. Clarkson, \& P. Robinson (Eds.). Designing Inclusive Interactions. Proceedings of the 2010 Cambridge Workshop on Universal Access and Assistive Technology (pp. 69-78). London: Springer-Verlag. http://dx.doi.org/10.1007/978-1-84996-166-0_7

Llanos de la Hoz, S. (2006). Impacto de las tecnologías de la información y la comunicación [Impact of information and communication technologies]. Agenda Académica, 7(1).

López, L., Méndez, E. M., \& Sorli, A. (2002). Evaluación de la accesibilidad y usabilidad de los sitios web de las bibliotecas públicas catalanas [Evaluation of accessibility and usability of Catalan public libraries' websites]. Item: Revista de Biblioteconomía i Documentació, 31, 17-51. Retrieved from http://e-archivo.uc3m.es/bitstream/10016/865/1/EMendez_Item.pdf

Marincu, C., \& McMullin, B. (2004). A comparative assessment of web accessibility and technical standards conformance in four EU states. Retrieved from http://firstmonday.org/htbin/cgiwrap/bin/ojs/index.php/fm/article/view/1160/1080

Metzger, M. (2007). Making sense of credibility on the web: Models for evaluating online information and recommendations for future research. Journal of the American Society for Information Science and Technology, 58(13), 2078-2091. http://dx.doi.org/10.1002/asi.v58:13

Ministerio de Trabajo y Asuntos Sociales. (2003). I Plan Nacional de Accesibilidad de 2004-2012. Por un nuevo paradigma, el Diseño para Todos, hacia la plena igualdad de oportunidades [I National Accessibility Plan 2004-2012. For a new paradigm, Designing for All, towards equal opportunities for everyone]. Madrid: Ministerio de Trabajo y Asuntos Sociales. Retrieved from http://www.sidar.org/recur/direc/legis/ipna2004_2012.pdf

Pérez, A., Linares, R., \& Vizcaino, R. (2007). Nuevos retos de la accesibilidad en los medios [New challenges for accessibility in the media]. TRANS, 11, 171-175.

Petrie, H., King, N., \& Hamilton, F. (2005). Museums, Libraries and Archives Council. Accessibility of museum, library and archive websites: The MLA audit. Retrieved from http://www.egovmonitor.com/reports/rep11278.pdf

Prendes, M. P., Castañeda, L., \& Ovelar, B. R. (2014). Componentes básicos para el análisis de los PLE de los futuros profesionales españoles: en los albores del proyecto CAPPLE [Basic components for the future professional's PLE analysis: In the beginning of the CAPPLE project]. EDUTEC. Revista Electrónica de Tecnología Educativa, 47.4 Retrieved from http://edutec.rediris.es/Revelec2/Revelec47/pdf/Edutec-e_n47_Prendes-Castaneda-Ovelar-Carrera.pdf

Riesco, R. (2009). Observatorio de Accesibilidad de la AGE. Un servicio de valor añadido que permite conocer el grado de cumplimiento de forma anual, en oleadas, de los portales públicos [AGE's Accessibility Observatory. An added-value service which permits to know the degree of compliance in public portals, on an annual basis and in waves]. Auditoria y Seguridad, 31. Retrieved from http://www.revista-ays.com/DocsNum31/Accesibilidad/Riesco.pdf

Ritchie, H., \& Blanck, P. (2003). The promise of the Internet for disability: A study of on-line services and website accessibility at centers for independent living. Behavioral Sciences and The Law, 21(1), 5-26. http://dx.doi.org/10.1002/bsl.520

Rodríguez, A., \& García, G. (2009). Medios de comunicación y discapacidad. Entre la accesibilidad y la interactividad [Mass media and disability. Between accessibility and interactivity]. Icono 14. Revista de Comunicación y Tecnología, 14(15), 303-319. http://dx.doi.org/10.7195/ri14.v8i1.296

Rodríguez, R., Codina, L., \& Pedraza, R. (2010). Cibermedios y web 2.0: Modelo de análisis y resultados de aplicación [Cybermedia and web 2.0: Analysis model and implementation results]. El Profesional de la Información, 19(1), 35-44. http://dx.doi.org/10.3145/epi.2010.ene.05

Sangrà, A., \& Wheeler, S. (2013). New Informal Ways of Learning: Or Are We Formalising the Informal? Universities and Knowledge Society Journal (RUSC), 10(1), 286-293. http://dx.doi.org/10.7238/rusc.v10i1.1689

Serrano, G. P., \& Capdevila, M. L. S. (2011). Information and communication technologies that promote social 
inclusion. Revista Española de Pedagogía, 69(249), 237-253.

Shah, B., \& Shakya, S. (2007). Evaluating the web accessibility of websites of the central government of Nepal. In T. Janowski, \& T. A. Pardo (Eds.), Proceedings of the 1st International Conference on Theory and Practice of Electronic Governance (pp. 447-448). New York, USA: ACM. http://dx.doi.org/10.1145/1328057.1328154

Stendal, K., Balandin, S., \& Molka-Danielsen, J. (2011). Virtual worlds: A new opportunity for people with lifelong disabilities. Journal of Intellectual and Developmental Disability, 36(1), 80-83. http://dx.doi.org/10.3109/13668250.2011.526597

Van Kraayenoord, C. (2010). Digital environments and individuals with disabilities: Some research needs. International Journal of Disability, Development and Education, 57(3), 241-244. http://dx.doi.org/10.1080/1034912X.2010.501267

Vigo, M., \& Brajnik, G. (2011). Automatic web accessibility metrics: Where we are and where we can go. Interacting with Computers, 23(2), 137-155. http://dx.doi.org/10.1016/j.intcom.2011.01.001

Zaphiris, P., \& Ellis, R. D. (2001). Website usability and content accessibility of the top USA universities. Proceedings of WebNet 2001 Conference (pp. 1380-1385). Orlando, Florida.

Zeng, X. M., \& Parmanto, B. (2004). Web content accessibility of consumer health information websites for people with disabilities: A cross sectional evaluation. Journal of Medical Internet Research, 6(2). http://dx.doi.org/10.2196/jmir.6.2.e19

\section{Notes}

Note 1. www.ine.es Data drawn from the 2008 Survey on Disability, Personal Autonomy and Dependency Situations

Note 2. Available at http://www.w3.org/TR/WCAG/

Note 3. Innovation and Communication Technology Centre (www.fundacionctic.org)

Note 4. http://www.tawdis.net

Note 5. http://ares.cnice.mec.es/matematicasep/pb/enlaces/comunidades.html (Consulted on April 24, 2014)

Note 6. Web depth level reflects the number of clicks needed to reach a page within a website. By way of example, accessing a page which is on web depth level 2 within a website or web portal requires one click (or clicking on one link) on the website homepage. Therefore, web depth level 1 corresponds to any content found on the homepage without clicking anywhere having needed any clicks.

\section{Copyrights}

Copyright for this article is retained by the author(s), with first publication rights granted to the journal.

This is an open-access article distributed under the terms and conditions of the Creative Commons Attribution license (http://creativecommons.org/licenses/by/3.0/). 